\title{
Remote Monitoring of Wind Speed and Produced Voltage Measured by Anemometer
}

\author{
Çağatay Ersin ${ }^{1 *}$, Ali Öz ${ }^{2}$, \\ ${ }^{1}$ Department of Electronics and Automation, Çankiri Karatekin University, Çankırı, Turkey, (ORCID: 0000-0001-5018-9313), cagatayersin@karatekin.edu.tr \\ 2 Department Of Motor Vehıcles And Transportatıon Technologies, Mehmet Akif Ersoy University, Burdur, Turkey, (ORCID: 0000-0002-0814-4020), \\ alioz@xmehmetakif.edu.tr
}

(First received 5 November 2021 and in final form 31 December 2021)

(DOI: 10.31590/ejosat.1019527)

ATIF/REFERENCE: Ersin, Ç. \& Öz, A., (2021). Remote Monitoring of Wind Speed and Produced Voltage Measured by Anemometer. European Journal of Science and Technology, (31), 986-990.

\begin{abstract}
Anemometer is a device used to measure wind speed at weather measurement stations. An Anemometer, which is used to measure the wind speed of an area, is widely used in weather stations. With the anemometer, wind speed and weather forecasts of a certain region are made. In this study, the wind speed values of a sample anemometer in a certain region and the voltage produced by the anemometer for wind energy were remotely monitored via the Internet of Things. In the system created, Arduino Uno microcontroller development board for the control of the system, a sample anemometer for measuring wind speed and generating voltage, LCD shield for displaying wind speed and voltage values on the screen, esp8266 wifi module for sending instant data from the anemometer to the thingspeak IoT platform and for feeding the system. Solar panels and battery charge regulators are used. In this study, the wind speed in a certain region and the monitoring of voltage produced depending on the wind speed was monitored on an internet basis. The system was operated in a certain region and the wind speed values and the generated voltage were monitored both instantaneously on the LCD screen and graphically on the thingspek an IoT platform as instantaneous, hourly, daily and weekly. With this system created, the thingview application was used for instant tracking on android devices.
\end{abstract}

Keywords: Anemometer, IoT, Esp8266, Solar Energy, Wind Energy

\section{Anemometre ile Ölçülen Rüzgâr Hızının ve Üretilen Gerilimin Uzaktan Takibinin Yapılması}

$\ddot{O ̈ z}$

Anemometre, hava durumu ölçüm istasyonlarında rüzgâr hızını ölçmek için kullanılan bir cihazdır. Bir bölgenin rüzgar hızını ölçmek için kullanılan anemometre hava durumu istasyonlarında yaygın olarak kullanılmaktadır. Anemometre ile belirli bir bölgenin rüzgar hızı, hava durumu tahmini yapılmaktadır. Yapılan bu çalışmada örnek bir anemometrenin belirli bir bölgedeki rüzgar hızı değerlerinin ve rüzgar enerjisi için anemometrenin ürettiği gerilimin nesnelerin interneti ile uzaktan takibi yapılmışıtr. Oluşturulan sistem de sistemin kontrolü için arduino uno mikrodentetleyici geliştirme kartı, rüzgar hızının ölçümü ve gerilim üretilmesi için örnek bir anemometre, rüzgar hızı ve gerilim değerlerinin ekranda gösterilmesi için LCD shield, anemometreden alınan anlık verilerin thingspeak IoT platformuna gönderilmesi için esp8266 wifi modül ve sistemin beslemesi için güneş paneli ve akü sarj regülatörü kullanılmıştır. Bu çalışma ile belirli bir bölgede rüzgâr hızı ve rüzgar hızına bağlı üretilen gerilimin takibi internet tabanlı olarak izlenmiştir. Sistem belrili bir bölgede çalıştıılmış ve rüzgâr hız değerleri ve üretilen gerilim hem LCD ekranda anlık olarak hemde thingspeka IoT paltfomunda anlık, saatlik, günlük ve haftalık olacak şekilde grafik halinde izlenmiştir. Oluşturulan bu sistem ile aynı zamanda android cihazlarda anlık takibi yapılması için thingview uygulaması kullanılmışıtr.

Anahtar Kelimeler: Anemometre, IoT, Esp8266, Güneş Enerjisi, Rüzgâr Enerjisi.

\footnotetext{
* Corresponding Author: cagatayersin@,karatekin.edu.tr
} 


\section{Introduction}

Energy is the source of economic development and social development. Rapid developments in industry and technology increase the energy needs of countries day by day. This situation has led countries to research new energy sources [1]. Wind energy is one of the clean and renewable energy sources. The main source of wind energy is the sun. Approximately $1-2 \%$ of the energy coming from the sun to the earth turns into wind energy. The temperature and pressure differences that occur because solar energy does not heat the land, sea and atmosphere equally everywhere create the wind. Wind energy is the kinetic energy of the air current that creates the wind [1]. To produce electricity by establishing a wind power plant in a region, the wind energy potential of the region must be determined. For this, wind speed and direction values should be measured continuously at regular intervals [1]. The most important device in wind measurements is the anemometer, which measures wind speed. [2nd]. Anemometer is the name given to the instruments used to measure the flow rates of air or other gases. The propeller anemometer generally has three blades mounted on a wheel hub. Propeller blades move in a vertical plane [3]. Developments in the Internet and wireless sensor networks enable data to be collected on-site, allowing for healthier planning and forecasting. Meteorological data tracking stations or automatic weather stations are systems used to measure and record known parameters of the atmosphere without human intervention. Meteorological data tracking stations or automatic weather stations are used for monitoring weather conditions, weather forecasting, long-term monitoring of climate change, ensuring healthy growth in plants, providing a healthy working environment in industry, collecting meteorological data for energy systems, predicting natural events such as floods, landslides or avalanches. is used [4].

The detection provided by Wireless Sensor Network (WSN) technologies, which is the main area of use of IoT (Internet of Things), is encountered in many areas of today's life. This offers the ability to measure, infer and understand environmental indicators from sensitive natural resources to urban environments. The proliferation of these devices in a communicative network creates the Internet of Things (IoT) [5]. In this study, an IoT application was carried out with a sample anemometer measuring wind speed. With the implemented system, the wind speed obtained from the anemometer and the voltage produced by the anemometer was monitored remotely via the thingspeak IoT platform.

\section{Material and Method}

\subsection{Internet of Things}

The Internet of Things (IoT) has been called the next Industrial Revolution or the next evolution of the Internet. IoT can be defined as an advanced and effective solution for connecting objects to the internet and collecting data from objects and sharing them over a network [4]. The Internet of Things can be defined as a communication network in which physical objects are connected or with larger systems. It can also be called connecting the data of objects or devices that they exchange with each other by constantly communicating with each other to a smart network. Changing the heating-cooling and ventilation conditions in the environment where the individual is or keeping the heatingcooling device at a certain setting in a certain period can be recorded as data and used later [6]. The concept of the Internet of
Things (IoT) was first mentioned in a presentation by Kevin Ashton in 1999 [1]. Objects are based on the idea of collecting the data of their environment on a common platform, analyzing them on this platform, making decisions and managing [1]. Thanks to the developing embedded systems, smaller sizes, less energy consumption, and easy programmability with wireless communication technologies, sensor nodes that receive the data in the environment can be designed [7]. In the internet of things, real-time and accurate data collection from sensors is one of the important functions. Generally, in sensor-based systems, various features of the environment, structure, or entity are sensed by sensors and sent to a base station and from there to a data processing centre over $\mathrm{WiFi}$, a wired communication infrastructure, or multi-hop links. After the data reaches the processing centre, smart decisions can be made based on the perceived information or the quality of the services provided can be improved [8].

\subsubsection{Thingspeak IoT Web Service}

Thingspeak is a web-based open API IoT resource information platform that is comprehensive in storing sensor data of various 'IoT applications' and outputs detected data in graphical form at the web level [8]. Thingspeak receives records/stores, analyzes, observes and works on the detected data from the connected sensor to the main microcontroller, with the help of the internet connection acting as a 'data packet' carrier between the connected 'objects' and the Thingspeak cloud. 'Arduino, TI CC3200 module, Raspberry-pi etc. As. Thingspeak is a fascinating sensor-based logging app, location/location tracking app and helps to keep the 'social network' of things/objects updated and alternatively, we can have a check. Via 'Home automation' products connecting from asset location to public area network (via the Internet) and the most basic feature of Thingspeak functionality is the term 'Channel' which is data area, location area, state area. for various detected data. Once channels are created in 'Thingspeak', the data can be applied and alternatively, you can process and visualize the information using MATLAB and respond to the data with tweets and other forms of alerts. Thingspeak also provides a public channel to analyze and predict this through the public [9].

\subsubsection{Anemometer}

As measuring devices, an anemometer is used for wind speed measurements and direction sensors are used for wind direction measurements. It will be extremely useful to measure some other meteorological parameters as well as wind speed and wind direction. It is important to measure pressure, ambient temperature and humidity values to calculate the air density used in wind energy calculations. In addition, measuring the solar radiation value will also be beneficial in the design of solar power plants to be made. The wind speed measurement height must be at least $30 \mathrm{~m}$ for wind energy measurements or the turbine hub height to be installed, and the measurements must be made periodically and continuously. In addition, the measurement height may change according to the topographic conditions of the land to be measured $[2,6]$. Anemometers are devices used to measure wind speed. Anemometers are sensors that convert wind speed into electrical signals. There are 3 types of anemometers: cup, ultrasonic and propeller anemometer. Cup anemometers are mostly used for wind speed measurements. These anemometers have a vertical axis and have 3 wind-catching cups. 
The number of revolutions per minute of the cups is recorded electronically and makes the wind measurement. In addition, special models with electrically heated shaft and cup anemometers can be used for measurement in cold climate conditions. Ultrasonic anemometers work with the principle of measuring the time elapsed while the sound wave emitted from each end is received by the other arm. In short, it makes measurements by distinguishing the phase shifts in the sound. The working principle of propeller anemometers is the same as cup anemometers. While cup anemometers are placed perpendicular to the wind direction, propeller anemometers are placed parallel to the blowing wind direction. In addition, this type of anemometer measures horizontal wind speed when mounted parallel to the wind direction and vertical wind speed when mounted vertically. The propeller anemometer is a built-in sensor. It can make both speed and direction measurements [1].

\subsection{Designing the Remote Tracking System}

In this study, the wind measurement speed and the voltage produced by the anemometer were followed on the Thingspeak IoT platform with a sample anemometer. Knowing the wind speed gives us information about the weather on an instant, daily or weekly basis. In addition, wind energy power, which is one of the renewable energy sources, in a certain region and the voltage produced by the anemometer could be monitored remotely thanks to this study. In the study, an Arduino Uno microcontroller development board was used to control the wind speed measured by a sample anemometer. The voltage produced by the anemometer depending on the wind speed was also controlled by the microcontroller. The block diagram of the created system is shown in Figure 1.

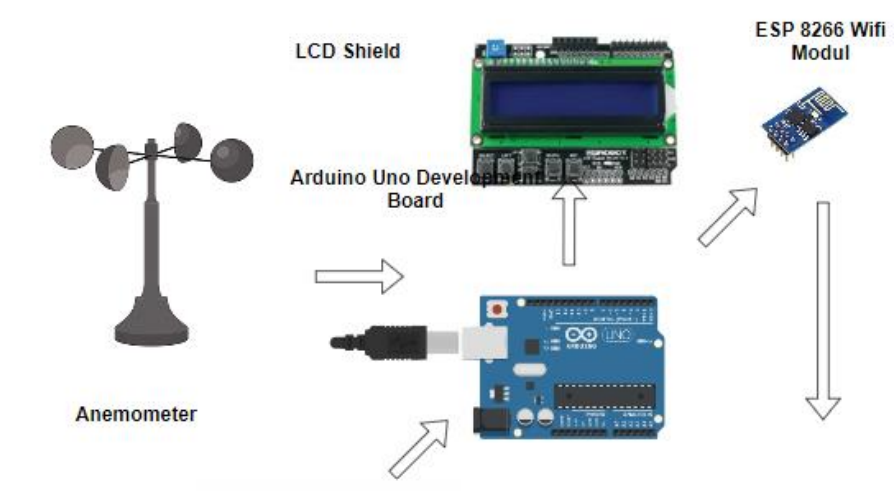

Battery Charge Controller
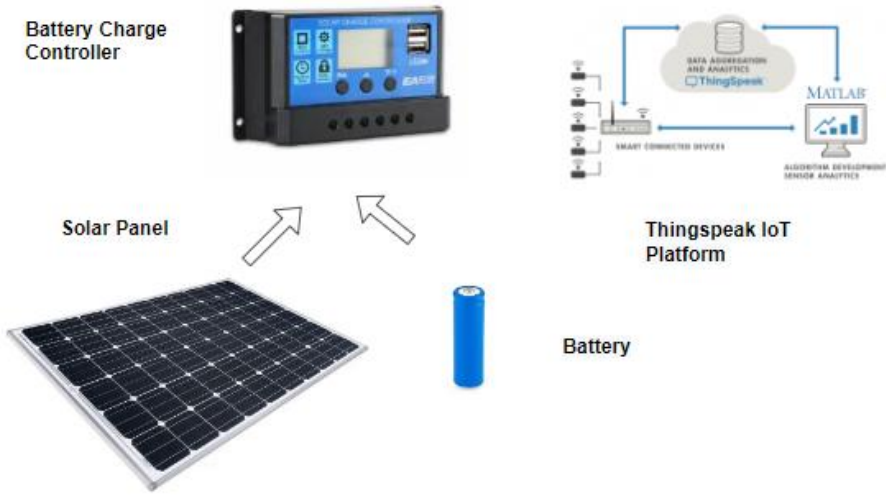

Thingspeak loT Platform

Battery

Figure 1. Block diagram of the system

In this study, the system was operated in a certain region and data related to two different parameters, namely wind speed and generated voltage, was obtained. The image of the created system is shown in Figure 2.

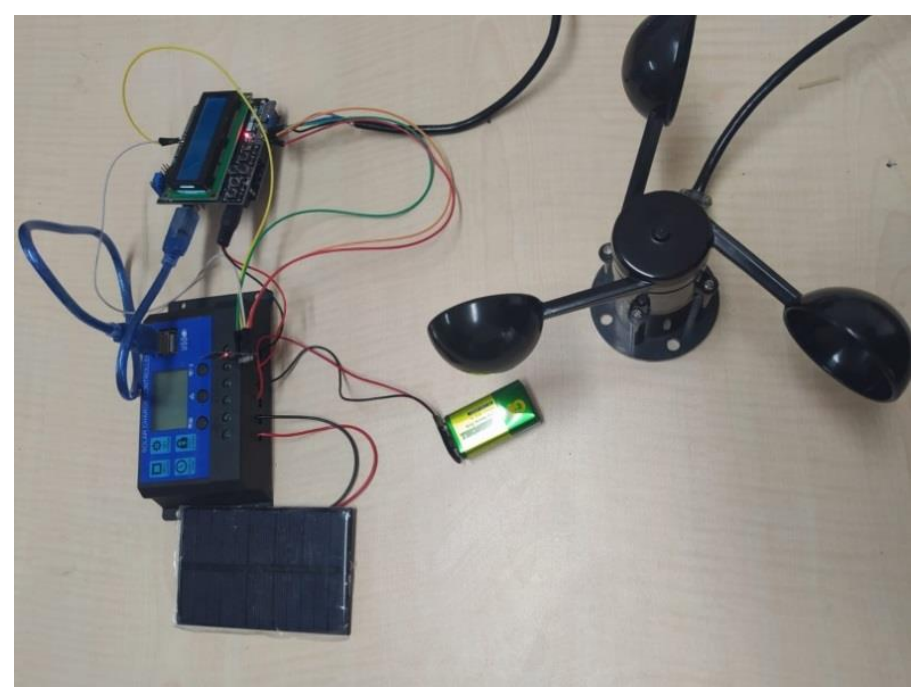

Figure 2. View of the system

An LCD screen was used to show the instantaneous wind speed values of the created system and the voltage produced by the wind turbine. Wind speed and generated voltage are displayed on the screen instantly. The voltage and instantaneous wind speed values produced by the anemometer are shown in Figure 3.

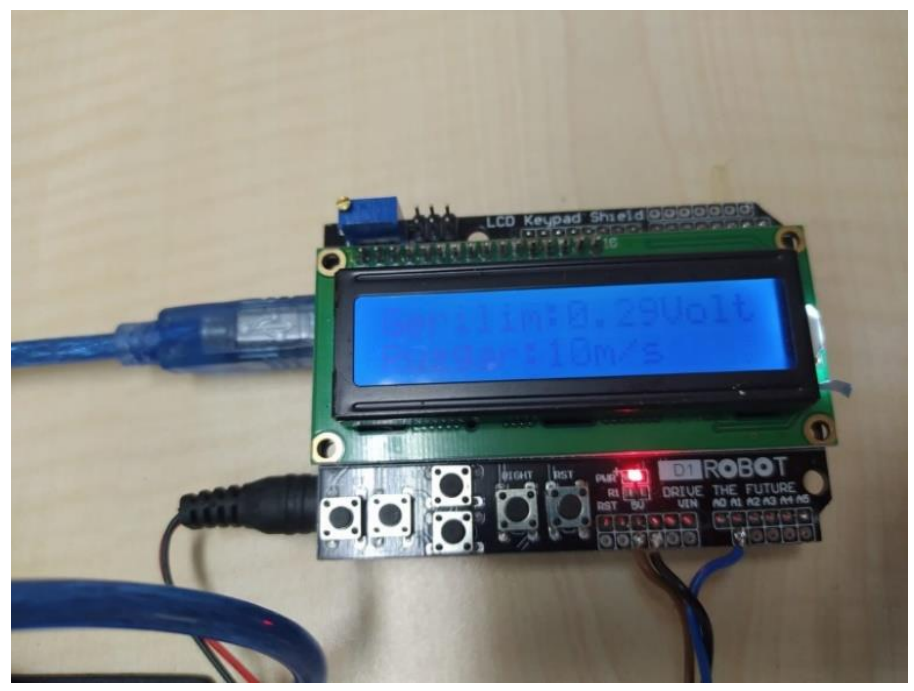

Figure 3. Display of wind speed and generated voltage on the LCD screen

In this study, the system was connected to the internet with the Esp8266 wifi module to monitor the wind speed and the voltage produced depending on the wind speed in the internet environment. The wind speed parameter measured by the microcontroller development board anemometer and the voltage produced were sent to the internet via Esp8266 wifi module. Esp8266 wifi module sent these two parameters to the thingspeak IoT web service application, which is frequently used in IoT studies, with wireless internet technology. These data were taken instantly from the thingspeak web address, which is the IoT (Internet of Things) platform, and transferred to two channels (measured wind speed and generated voltage) opened in the thingspeak account. The instantaneous incoming data to these two channels have been converted into a graphic, and according to the time of the incoming data, instant, hourly, weekly, daily or even monthly follow-ups can be made. In addition, the location of the 
region where the system is used is shown with a channel opened on the thingspeak IoT platform. The screenshot of wind speed and generated voltage channels in the Thingspeak IoT platform is shown in Figure 4.

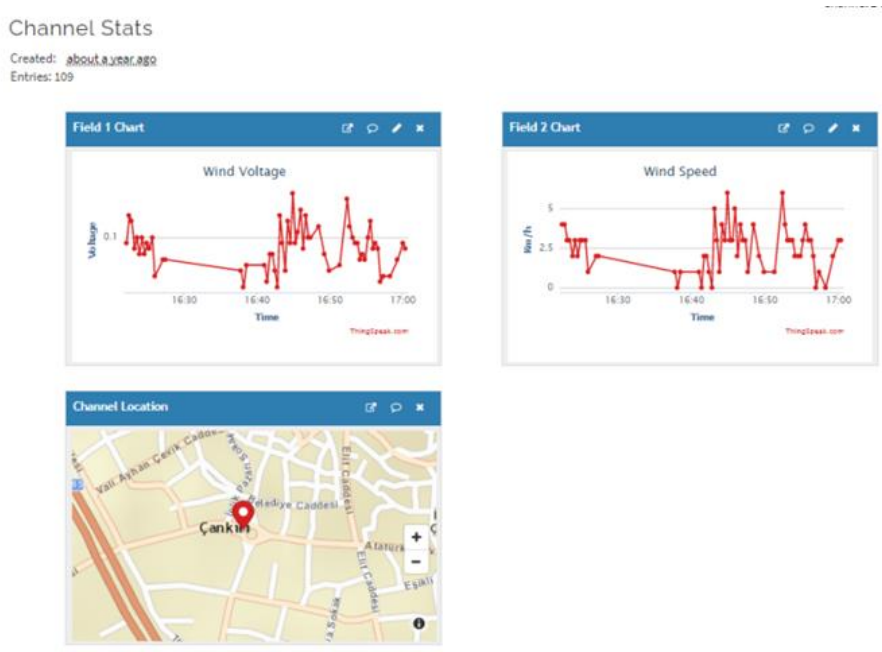

Figure 4. The generated tension channel and wind speed
channel image

The system has been installed and tested in a specific region. The system is connected to the internet through internet providers in that region. With the location determination, which is a feature of the Thingspeak IoT platform, the region where that wind measurement was made was found and shown in a channel. The data received by the system and the screenshot of the channels opened on the Thingspeak IoT platform are shown in Figure 5.

Channel Stats

Created: about a year ago
Last entry: about 24hours.agg
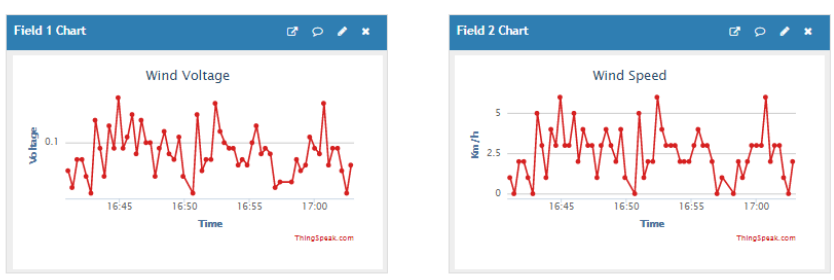

\section{Figure 5. Data from Anemometer and Thingspeak channel}

In this study, instantaneous wind speed values measured by a sample anemometer and voltages produced depending on wind speed were instantly followed on the Thingspeak internet address. Thanks to this system created, the user will have remote information about the voltage produced by the anemometer and the wind turbine without going to the region, and about the wind speed of that region. The user will also be able to make long-term comments about the voltage and wind speed produced using the thingspeak web address. It has also been integrated into the thingview software, which is the android application of the thingspeak IoT platform, to make the use of the system more widespread and simpler to use. The user will be able to access the wind speed and the generated voltage values in the region where the anemometer is located, with any android device. The screenshot of Thingview android software is shown in figure 6 .

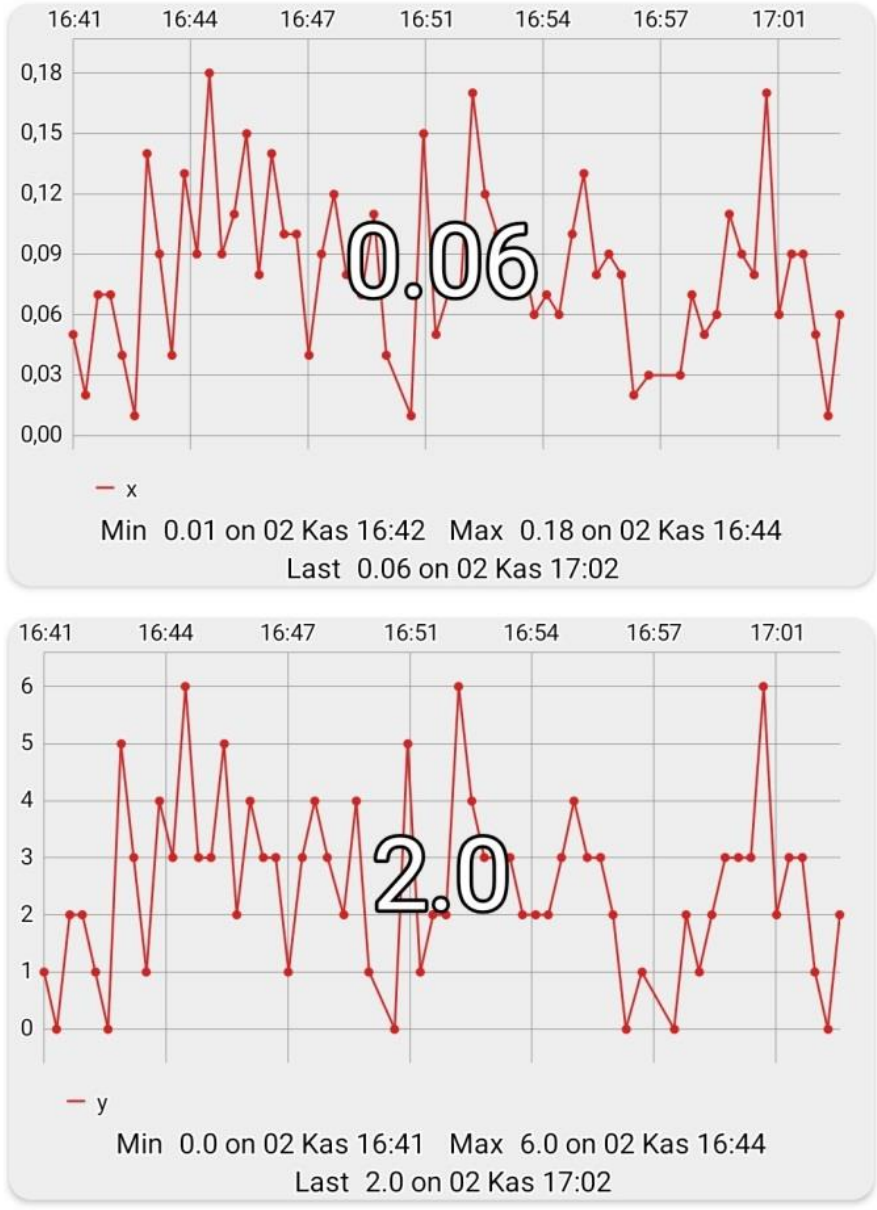

Figure 6. Screenshot of Thingview android software

\section{Results and Discussion}

Wind speed in a region is highly correlated with the pressure gradient in that region. The formation of pressure differences in the region increases the wind speed. In this study, a sample anemometer was provided to measure wind speed. The anemometer measured the wind speed and accordingly acted as a wind turbine and produced a voltage. A microcontroller development board is used in the system to control these two parameters. The system was operated in a specific region. The wind speed and generated voltage values in the operating area were instantly sent to the thingspeak internet address via the IP address with the wifi module in the system. Data related to these two parameters

The location of the system established by adding the location of the region where it is located and converted into graphics on the Thingspeak IoT platform is shown in Thingspeak. Since the system will also work as wind energy, the system is powered by a solar panel battery and battery charge controller. The system takes its energy from the sun. Thus, this system will be able to work in all regions with solar energy. In this study, the system was tested in a certain region and 109 pieces of data were taken depending on 2 parameters: wind speed and generated voltage. These data received by the system give us information about the weather conditions of that region and the rate of benefiting from wind energy. An exemplary anemometer in the system was operated like a wind turbine, and it was observed that it produces an average voltage of 0.12 volts in places where the wind speed is 4 $\mathrm{m} / \mathrm{s}$. The system was designed as a prototype and set an example for large turbines and anemometers. In this study, by using a real 
wind turbine instead of the anemometer in this study, the wind speed and the generated voltage will be monitored remotely from the internet or an android device.

\section{References}

[1]Faruk, O. R. A. L., \& Behçet, R. Rüzgar Verilerinin Enerji Üretimi Amaçlı Değerlendirilmesi. Bitlis Eren Üniversitesi Fen Bilimleri Dergisi, 4(2).

[2]Oğuzer, C. (2001). Rüzgâr Ölçüm Sistemlerinin Esasları.

[3]Bakir, E. (2017). Enerji Depolamalı Yeni Nesil Fotovoltaik/Termal Kolektörlerin Isıl Performanslarının Incelenmesi/Investigation Of Thermal Performance Of New Generation Photovoltaic/Thermal Collectors With Energy Storage.

[4]Kelebekler, E. (2019). Nesnelerin İnterneti Tabanlı Meteorolojik Veri Takip Sistemi. Düzce Üniversitesi Bilim Ve Teknoloji Dergisi, 7(1), 650-663.

[5]Ersin, C.., Mustafa, Y. A. Z., \& Karhan, M. Savunma Sanayi İçin Örnek Bir IoT Uygulaması. Electronic Letters on Science and Engineering, 15(3), 66-73.

[6]Korukçu, M. Ö., \& Kiliç, M. Isil Konfor İçin Nesnelerin İnterneti Kullanimi.

[7]Sazak, T., \& Albayrak, Y. (2017). Nesnelerin İnterneti (Iot) Üzerine Ortam Verilerini Toplayan Ve Uzaktan Takibini Sağlayan Bir Sistem Tasarımı, 19. Akademik Bilişim Konferans1-Ab, 8-10.

[8]Pasha, S. (2016). ThingSpeak based sensing and monitoring system for IoT with Matlab Analysis. International Journal of New Technology and Research (IJNTR), 2(6), 19-23.

[9]Akram, V., \& Dağdeviren, O. (2020). Nesnelerin İnterneti Için Gerçek Zamanlı Tasarsız Veri Toplama Platformu. Bilişim Teknolojileri Dergisi, 13(4), 451-462. 